\title{
KREDIBILITAS PUSTAKAWAN DALAM MEMBERIKAN INFORMASI ISI KOLEKSI LAYANAN ANAK DI DINAS PERPUSTAKAAN DAN KEARSIPAN KABUPATEN KONAWE
}

\author{
Andi Asriani Umar ${ }^{1}$, Marsia Sumule G. ${ }^{2}$, Asrul Jaya ${ }^{3}$ \\ ${ }^{123}$ Program Studi Perpustakaan dan Ilmu Informasi Fakultas Ilmu Sosial dan Ilmu Politik Universitas Halu \\ Oleo \\ Jl. H.E.A. Mokodompit No.1, Kota Kendari, Indonesia \\ E-mail: Andiasrianiumar1@gmail.com
}

\begin{abstract}
ABSTRAK
Tujuan dari penelitian ini adalah untuk mengetahui Kredibilitas Pustakawan Dalam Memberikan Informasi Isi Koleksi Layanan Anak di Dinas Perpustakaan Dan Kearsipan Kabupaten Konawe. Metode penelitian yang digunakan dalam penelitian ini adalah metode penelitian deskriptif kualitatif. Teknik penentuan informan dalam penelitian ini adalah purposive sampling dengan jumlah informan sebanyak 8 orang. Teknik pengumpulan data yang digunakan dalam penelitian ini yaitu observasi, wawancara dan dokumentasi. Hasil penelitian ini menunjukan bahwa Pustakawan layanan anak dalam memberikan informasi isi koleksi pada Dinas Perpustakaan dan Kearsipan Kabupaten Konawe sudah memiliki kredibilitas cukup baik yang ditunjukkan pada tiga indikator. Pada indikator keterpercayaan, pustakawan berupaya bersikap tulus, terbuka dan sabar dalam melayani pemustaka anak meskipun sikap terbuka dan sabar yang dimiliki belum sepenuhnya. Indikator keahlian, pustakawan sudah memiliki pengetahuan tentang perpustakaan dan mengenai keterampilan, pustakawan menerapkan penyesuaikan usia pemustaka dengan bahan bacaan, melakukan kegiatan mendongeng dan membantu pemustaka anak yang kesulitan memperoleh informasi dari bahan bacaan karena keterbatasan belum bisa membaca meskipun bantuan tersebut belum konsisten dilakukan dan pada indikator daya tarik, pustakawan senantiasa memperhatikan penampilan dalam hal ini selalu menjaga kerapian dan mengikuti aturan berpakaian yang sudah ditetapkan. Berkaitan dengan daya tarik psikologis dalam hal ini kaitannya dengan kedekatan antara pemustaka dan pustakawan, interaksi sengaja dibentuk pendekatan antara Ibu dan Anak. Selain itu terdapat daya tarik lain yang berasal dari dekorasi ruangan layanan anak yang disesuaikan dengan karakteristik anak, penyediaan fasilitas pendukung dan mengadakan kegiatan seperti pemutaran film.
\end{abstract}

Kata Kunci : Kredibilitas, Pustakawan, Pemberian Informasi, Layanan Anak

\section{ABSTRACT}

The purpose of this research is to know the Credibility of Librarians in Providing Information on The Contents of Children's Service Collections at Service Collection at the library and archives of konawe regency. The research method used in this study is a qualitative descriptive research method. The technique of informant determination in this study is purposive sampling with 8 informants. The data collection techniques used in this study are observation, interview and documentation. The results of this study show that the Librarian of children's services in providing information on the contents of children's service collection at the library and archives of konawe regency already has quite good credibility shown in the three indicators. On indicator of trustworthiness, librarians strive to be sincere, open and patient in serving children even though their open and patient attitude is not yet fully shared. In expertise indicator, librarians already have knowledge of libraries and then about skills, librarians apply age adjusters to reading materials, conduct storytelling activities and help children who have difficulty obtaining information from reading materials because of the limitations of not being able to read even though the help has not been consistently done and on the attractiveness indicator, librarians always pay attention to appearance in this case always keeping the neatness and following the established dresscode. About psychological attractiveness, related to the closeness between library visitors and librarians where the interaction is deliberately designed approach like between Mother and Child. In addition there are other attractions that come from decorating children's services rooms that are tailored to the characteristics of the child, the provision of supporting facilities and holding activities such as film screenings.

Key Words : Credibility, Librarians, Providing Informations, Children's Services 


\section{PENDAHULUAN}

Perpustakaan umum merupakan unit kerja/lembaga/badan yang diselenggarakan di wilayah penduduk untuk semua lapisan dan kalangan masyarakat penduduk wilayah tersebut guna melayani kebutuhan informasinya. Perpustakaan umum ditujukan kepada masyarakat luas untuk sarana pembelajaran seumur hidup tanpa membedakan usia, jenis kelamin, suku, ras, agama, dan status sosial ekonomi. Perpustakaan umum menyediakan berbagai jenis koleksi untuk seluruh lapisan usia mulai dari anak-anak, remaja, dewasa hingga lanjut usia, baik untuk laki-laki maupun perempuan. Oleh karena itu perpustakaan umum selalu terus berusaha untuk memenuhi kebutuhan masyarakat semua usia termasuk salah satunya layanan yang diperuntukkan bagi anak-anak yang sering dikenal sebagai layanan anak di perpustakaan. Layanan anak merupakan layanan yang ditujukan untuk anak-anak yang diselenggarakan oleh perpustakaan sesuai dengan tugas dan fungsi perpustakaan umum yaitu, memberikan pelayanan kepada masyarakat melalui pendayagunaan koleksi bahan pustaka untuk keperluan pendidikan, penelitian, ilmu pengetahuan, dan rekreasi.

Seseorang yang aktif memberikan bantuan atas kebutuhan pemustaka adalah pustakawan. Secara lebih jelas, tugas pustakawan adalah memberikan pelayanan, bimbingan arahan agar para pemustaka dapat memanfaatkan perpustakaan semaksimal mungkin dalam memperoleh informasi yang dibutuhkan. Sebagai pemberi layanan dan penyedia informasi di perpustakaan, seorang pustakawan harus memiliki kemampuan, keterampilan, intlektual, berkomunikasi, berinteraksi dan terutama dalam menunjukkan pengakuan pemustaka terhadap kredibilitas yang melekat pada diri sebagai pustakawan.

Keberadaan pustakawan sangat penting untuk menjalani layanan anak yang telah ada. Layanan yang baik yang diberikan untuk anak-anak di perpustakaan diawali oleh pustakawan yang terlatih dan mempunyai dedikasi yang tinggi. Pustakawan anak merupakan seseorang yang mengkhususkan diri dalam layanan dan koleksi untuk anak hingga dengan umur 12-13 tahun. Selain itu seorang pustakawan anak adalah orang yang gemar membaca dan mempunyai antusiasme pada bacaan anak, sehingga dapat membimbing dan menjadi tempat bertanya bagi para pemustakanya dalam hal ini anak-anak.

Salah satu perpustakaan umum daerah yang menyediakan layanan anak adalah Dinas Perpustakaan dan Kearsipan Kabupaten Konawe, merupakan salah satu perpustakaan yang terletak di Sulawesi Tenggara. Berdasarkan hasil observasi yang telah peneliti lakukan berkaitan dengan kredibilitas pustakawan di Dinas Perpustakaan dan Kearsipan Kabupaten Konawe, pustakawan yang ditempatkan di layanan anak cenderung terlambat datang dan pulang sebelum jam layanan selesai dan terkadang meninggalkan dan membiarkan anak-anak di ruangan tanpa ada pengawasan dan bimbingan. Berangkat dari hal tersebut sehingga memotivasi peneliti untuk melakukan riset dengan judul, "Kredibilitas Pustakawan Dalam Memberikan Informasi Isi Koleksi Layanan Anak di Dinas Perpustakaan Dan Kearsipan Kabupaten Konawe."

Tentunya dilakukannya penelitian ini bertujuan untuk mengetahui kredibilitas pustakawan dalam memberikan informasi isi koleksi layanan anak di Dinas Perpustakaan dan Kearsipan Kabupaten Konawe. Penelitian ini diharapkan dapat turut serta dalam usaha pengembangan Ilmu Informasi dan Perpustakaan yang berkaitan dengan kredibilitas pustakawan dalam memberikan informasi isi koleksi layanan anak. Hasil penelitian ini juga diharapkan dapat memberikan masukan bagi Dinas Perpustakaan dan Arsip Daerah Kabupaten Konawe tentang kredibilitas pustakawan dalam memberikan informasi isi koleksi layanan anak. Selain itu, hasil penelitian ini juga diharapkan dapat membantu sebagai bahan perbandingan bagi peneliti berikutnya yang berkaitan dengan kredibilitas pustakawan dalam memberikan informasi isi koleksi layanan anak.

Menurut Rakhmat (2012:257) Kredibiltas adalah seperangkat persepsi komunikate tentang sifat-sifat komunikator. Dalam hal ini terkandung dua hal: pertama kredibilitas merupakan persepsi khalayak, jadi tidak inhern dalam diri komunikator, kedua kredibilitas berkenaan dengan sifat-sifat komunikator. Hovland menggambarkan peranan kredibilitas dalam proses penerimaan pesan dengan mengemukakan para ahli akan lebih persuasif dibandingkan dengan bukan ahli. Suatu pesan persuasif akan lebih efektif apabila kita mengetahui bahwa penyampai pesan adalah orang yang ahli dibidangnya (Azwar, 2011:64). 
Teori kredibilitas sumber (source kredibility theory) pertama kali dikemukakan oleh Hovland, Janis dan Kelly dalam buku Communication and Persuasion pada tahun 1953. Adapun yang menjadi asumsi dari teori ini menyatakan bahwa orang akan lebih mungkin dipersuasi ketika komunikator atau orang yang menyampaikan pesan komunikasi menunjukkan dirinya sebagai orang yang kredibel atau dengan kata lain sumber komunikasi yang memiliki kredibilitas tinggi akan lebih efektif dalam mengubah opini seseorang dibandingkan dengan sumber komunikasi yang sumber kredibiltasnya rendah (Winoto, 2015:1). Penelitian yang telah dilakukan oleh Hovland, Janis dan Kelley sebelumnya yang menemukan tiga aspek yang mempengaruhi kredibilitas sumber (Sigar, 2017:6-7), yakni (1) keterpercayaan (trustworthiness), (2) keahlian (expertise), dan (3) daya tarik (attratctiveness).

Menurut Undang-Undang Nomor 43 Tahun 2007 pasal 1 ayat 8 tentang Perpustakaan menyatakan bahwa pustakawan adalah seseorang yang memiliki kompetensi yang diperoleh melalui pendidikan dan/atau pelatihan kepustakawanan serta mempunyai tugas dan tanggung jawab untuk melaksanakan pengolahan dan pelayanan perpustakaan. Sedangkan menurut Suwarno (2011:33), pustakawan atau librarian adalah seorang tenaga kerja bidang perpustakaan yang telah memiliki pendidikan ilmu perpustakaan, baik melalui pelatihan, kursus,seminar, maupun dengan kegiatan sekolah formal. Pustakawan ini orang yang bertanggung jawab terhadap gerak maju roda perpustakaan. Adapun menurut Mulyadi (2011:4-5), pustakawan adalah pejabat fungsional yang berkedudukan sebagai pelaksana penyelenggara tugas utama kepustakawanan pada unit-unit perpustakaan, dokumentasi, dan informasi dan instansi pemerintah.

Seperti yang terdapat pada buku Petunjuk Teknis Jabatan Fungsional Pustakawan dan Angka Kreditnya dalam Nasrullah (2015:27) terdiri dari; (1) Tugas pokok Pustakawan Tingkat Terampil meliputi pengorganisasian dan pendayagunaan koleksi bahan pustaka atau sumber informasi, pemasyarakatan perpustakaan, dokumentasi dan informasi; (2) tugas pokok Pustakawan Tingkat Ahli meliputi pengorganisasian dan pendayagunaan koleksi bahan pustaka atau sumber informasi, pemasyarakatan perpustakaan, dokumentasi dan informasi serta pengkajian pengembangan perpustakaan, dokumentasi, dan informasi. Sedangkan peran pustakawan menurut Hermawan dan Zulfikaz dalam Nasrullah (2017:71-74) dapat disingkat dengan akronim EMAS, yaitu (1) edukator, (2) manajer, (3) administrator, dan (4) supervisor.

Informasi adalah sekumpulan fakta (data) yang diorganisasikan dengan cara tertentu sehingga mereka mempunyai arti bagi si penerima (Sutarman, 2012:14). Adapun menurut McLeod dalam Yakub (2012:8) Informasi adalah data yang diolah menjadi bentuk yang lebih berguna bagi penerimanya. Deni Darmawan \& Kunkun Nur Fauzi (2013:2) mengatakan bahwa informasi merupakan hasil dari pengolahan data, akan tetapi tidak semua hasil dari pengolahan tersebut bisa menjadi informasi, hasil pengolahan data yang tidak memberikan makna atau arti serta tidak bermanfaat bagi seseorang bukanlah merupakan informasi bagi orang tersebut.

Menurut Sutarman (2012:14), Nilai dari informasi ditentukan oleh lima hal yaitu, (1) untuk memperoleh pemahaman dan manfaat; (2) untuk mendapatkan pengalaman; (3) pembelajaran yang terakumulasi sehingga dapat diaplikasikan dalam pemecahan masalah atau proses bisnis tertentu; (4) untuk mengekstrak inplikasi kritis dan merfleksikan pengalaman masa lampau yang menyedikan pengetahuan yang terorganisasi dengan nilai yang tinggi; (5) suatu informasi dikatakan bernilai bila manfaatnya lebih efektif dibandingkan dengan biaya mendapatkannya. Sedangkan kualitas informasi menurut Mc Leod dalam Azhar Susanto (2013:38) harus memiliki ciri-ciri yaitu, (1) akurat (accuracy), (2) relevan (relevancy), (3) tepat waktu (timeliness), (4) lengkap (complete).

Layanan anak menurut Sutarno dalam Akbar (2017:19) yaitu suatu kegiatan di perpustakaan dalam rangka melayani pembaca dan pengunjung kelompok/seksi anak-anak. Layanan anak adalah layanan yang biasanya diberikan untuk anak-anak mulai dari anak-anak usia prasekolah sampai tingkat menengah pertama atau paling tidak sampai tingkat sekolah dasar. Layanan perpustakaan anak adalah bagian penting yang tak terpisahkan dari perpustakaan umum, karena anak-anak adalah bagian dari masyarakat secara umum, dimana merekalah yang menjadi tujuan atau sasaran dari layanan yang disediakan perpustakaan umum tersebut (Yusuf dalam Zulharmain, 2015:14). 
Perpustakaan daerah adalah perpustakaan umum yang berada disetiap kabupaten dan kota merupakan perpustakaan yang diadakan dengan tujuan untuk melayani masyarakat dalam hal penyediaan akses terhadap informasi, dan mendorong masyarakatnya keluar dari kesulitan dan kebuntuan (Sulistyo-Basuki dalam Larasati, 2011:14). Menurut Reitz dalam Wendri (2018:24) perpustakaan daerah adalah sebuah perpustakaan atau sistem perpustakaan yang mencakup akses untuk sumber dan layanan perpustakaan yang gratis untuk semua kalangan, daerah, dan wilayah geografis, yang didukung dari pembiayaan masyarakat.

\section{METODE PENELITIAN}

Penelitian ini dilaksanakan di Dinas Perpustakaan Dan Kearsipan Kabupaten Konawe, Jl. Pangeran Diponegoro No.400, Kelurahan Lalosabila, Kecamatan Wawotobi, Kabupaten Konawe, Provinsi Sulawesi Tenggara. Penelitian ini adalah penelitian kualitatif, dengan subjek penelitian adalah seluruh pegawai dan seluruh pemustaka Dinas Perpustakaan Dan Kearsipan Kabupaten Konawe. Teknik pengumpulan data menggunakan metode observasi, wawancara, dokumentasi, dan studi pustaka. Data penelitian yang diperoleh dianalisis menggunakan analisa deskripsi kualitatif.

\section{HASIL DAN PEMBAHASAN}

Untuk mengetahui Kredibilitas Pustakawan dalam memberikan Informasi Isi Koleksi Layanan Anak di Dinas Perpustakaan dan Kearsipan Kabupaten Konawe, penulis telah mendapatkan data dengan cara menggunakan metode observasi dan wawancara dengan Kepala Bidang Layanan, Pustakawan Layanan Anak, dan Pemustaka Anak. Kemudian penulis mendeskripsikan dan membahas tentang hasil temuan yang ditemukan terkait dengan kredibilitas pustakawan dalam memberikan informasi isi koleksi layanan anak. Pendeskripsian tersebut didasarkan pada tiga komponen kredibilitas, yakni: keterpercayaan, keahlian, dan daya tarik.

Keterpercayaan, ini berkaitan dengan kesan khalayak mengenai pembicara yang berkaitan dengan aspek kepribadiannya. Keterpercayaan merupakan penilaian hubungan seseorang dengan orang lain. Kepercayaan pemustaka terhadap pustakawan dapat terbentuk melalui sikap ketulusan, keterbukaan dan kesabaran yang dimiliki oleh pustakawan dalam melayani pemustaka.

Ketulusan identik dengan keikhlasan, sehingga orang yang memiliki ketulusan dalam memberikan bantuan tidak mengharapkan pamrih. Berdasarkan hasil wawancara dari beberapa informan penelitian dapat disimpulkan bahwa pustakawan layanan anak pada Dinas Perpustakaan dan Kearsipan Kabupaten Konawe telah bersikap tulus dalam memberikan pelayanan kepada pemustaka yang berkunjung dengan tidak mengharapkan pamrih. Hal ini tercermin dari tidak adanya pungutan biaya apapun dari pemustaka baik itu dari segi penggunaan layanan dan fasilitas yang ada, pembuatan kartu anggota perpustakaan maupun denda pengembalian buku yang dipinjam oleh pemustaka. Dengan adanya sikap ketulusan yang ditunjukkan oleh pustakawan pada saat memberikan layanan bertujuan untuk menimbulkan kepercayaan pemustaka unuk terus menggunakan layanan dan fasilitas yang disediakan perpustakaan dan dapat memelihara hubungan antara pustakawan dengan pemustaka agar dapat melakukan interaksi secara efektif yang bisa menjadi kunci sukses dalam keberhasilan suatu layanan.

Keterbukaan yaitu kemampuan menanggapi dengan senang hati infomasi yang diterima dalam menghadapi komunikasi antarpribadi. Berdasarkan hasil wawancara bersama beberapa informan mengenai sikap keterbukaan, dapat disimpulkan bahwa pustakawan sudah menerapkan sikap terbuka dengan mengajak pemustaka anak berkomunikasi menanyakan kebutuhan informasinya, merespon pertanyaan yang diberikan oleh pemustaka, dan membantu pemustaka menemukan koleksi yang dibutuhkan. Namun penerapan sikap terbuka oleh pustakawan belum sepenuhnya dikarenakan pustakawan melakukan pembatasan penggunaan fasilitas oleh pemustaka dalam hal ini mainan hanya boleh di gunakan sebagian pada hari kunjungan biasa. Padahal dengan adanya keterbukaan dapat menghasilkan kepercayaan, dan dengan kepercayaan akan mendapatkan hubungan yang baik pula karena jika bersikap terbuka 
dengan otomatis level kepercayaan seseorang akan meningkat dan itu akan mempererat hubungan.

Kesabaran adalah rasa sanggup menanggung hal-hal yang tidak mengenakkan hati dan menahan diri dari keluh kesah. Dapat disimpulkan bahwa pustakawan layanan anak Dinas Perpustakaan dan Kearsipan Kabupaten Konawe senantiasa berusaha bersikap sabar dalam memberikan informasi, namun adakalanya pustakawan tidak bisa mengendalikan diri yakni ketika pemustaka anak bertingkah seperti terlalu berisik, keseringan keluar masuk ruangan, menghambur koleksi, menggunakan fasilitas namun tidak mengembalikan ke tempat semula. Selain itu pustakawan akan sensitif dan sulit untuk sabar pada saat keadaan psikologis yang tidak normal yaitu ketika pustakawan dalam keadaan sedang banyak beban pikiran. Akan tetapi jika kita mampu bersikap sabar, hal itu akan mampu menciptakan kesan baik dari pemustaka sehingga menimbulkan rasa kepercayaan kepada pustakawan, dan hal tersebut juga akan berpengaruh pada keinginan pemustaka untuk terus menggunakan layanan di perpustakaan.

Keahlian merupakan kesan yang dibentuk tentang kemampuan pustakawan dalam hubungannya dengan topik yang dibicarakan dan dengan hal yang dilayankan. Keahlian seorang pustakawan tercermin dalam pengetahuan dan keterampilan ketika memberikan pelayanan informasi kepada pemustaka.

Berbicara mengenai pengetahuan, tentunya seorang pustakawan idealnya harus memiliki latar belakang pendidikan ilmu perpustakaan baik secara formal maupun melalui pelatihan. Berdasarkan hasil wawancara bersamaa beberapa informan, dapat diketahui bahwa pada Dinas Perpustakaan dan Kearsipan Kabupaten Konawe memiliki empat orang yang berlatar belakang pendidikan Ilmu Perpustakaan. Keempat orang tersebut dengan sengaja disebar di setiap layanan dengan tujuan untuk melakukan penyetaraan kualitas pelayanan. Pihak perpustakaan meyakini bahwa dengan pembagian penempatan orang yang memiliki pengetahuan yang berlatar belakang perpustakaan disetiap layanan akan berkembang lebih baik.

Keterampilan seorang pustakawan sangat diharapkan. Hal ini dikarenakan bahwa seorang pustakwan banyak berinteraksi dengan pemustaka yang datang silih berganti untuk mencari informasi yang berbeda-beda. Dari beberapa hasil wawancara bersama informan penelitian, dapat dipahami bahwa pustakawan layanan anak Dinas Perpustakaan dan Kearsipan Kabupaten Konawe memiliki keterampilan yang digunakan pada saat memberikan informasi dan layanan. Keterampilan yang dimiliki pustakawan layanan anak, antara lain memiliki kemampuan untuk mengarahkan pemustaka anak mendapatkan bahan bacaan sesuai usia, membantu pemustaka anak yang hendak mengetahui isi suatu koleksi namun terbatas karena belum bisa membaca, dan pustakawan memiliki keterampilan mendongeng. Dengan keterampilan-keterampilan yang dimiliki oleh pustakawan tersebut dapat membangun dan menanamkan image positif perpustakaan serta mampu menyajikan layanan prima untuk memenuhi kebutuhan informasi pemustaka, dan juga akan membawa kesuksesan dalam pekerjaan dan tentunya membawa keuntungan bagi dirinya karena keterampilan mampu menjalin komunikasi dan hubungan yang harmonis dengan pemustaka.

Daya Tarik seseorang tidak hanya dilihat dari bagaimana ia menimbulkan keterpercayaan dan keahlian yang dimiliki. Daya tarik memiliki kaitan erat dengan tampilan fisik dan psikologis. Pustakawan pada Dinas Perpustakaan dan Kearsipan Kabupaten Konawe telah memperhatikan daya tarik fisik dalam hal ini cara berpakaian selalu menjaga kerapian dan selalu menyesuaikan dengan aturan berpakaian yang telah ditetapkan. Penampilan pustakawan yang menarik bisa menjadi daya tarik tersendiri untuk ketertarikan pemustaka pada pustakawan sehingga berpengaruh terhadap komunikasi antara pustakawan dan pemustaka. Selain memiliki daya tarik fisik, Pustakawan Layanan Anak Dinas Perpustakaan dan Kearsipan Kabupaten Konawe juga memiliki daya tarik psikologis, yaitu kedekatan yang dengan secara sengaja didesain menggunakan prinsip kesamaan dengan interaksi antara Ibu dan Anak. Faktor kesamaan merupakan salah satu faktor penentu keberhasilan komunikasi oleh karena itu dengan adanya kesamaan pendekatan antara ibu dan anak yang digunakan oleh pustakawan layanan anak tersebut bertujuan agar dapat menjalin hubungan komunikasi yang baik dengan pemustaka anak.

Terdapat daya tarik lain yang bisa dimunculkan oleh pustakawan yaitu dari segi tampilan dan fasilitas yang dimiliki perpustakaan itu sendiri. Berdasarkan hasil observasi, penulis melihat 
ruang layanan anak Dinas Perpustakaan dan Kearsipan Kabupaten Konawe didekorasi lebih berwarna disesuaikan dengan pembawaan anak-anak yang ceria. Dapat disimpulkan bahwa daya tarik juga di bentuk oleh pustakawan dari segi penampilan perpustakaan dalam hal ini pada layanan anak ruangannya disesuaikan dengan selera dan kebutuhan pemustaka anak yakni ruangan yang lebih berwarna, penyediaan fasilitas penunjang kegiatan membaca dan mainan edukatif yang berguna untuk meningkatkan daya intelektual dan imajinasi serta sebagai sarana rekreasi yang tentunya mendidik.

\section{KESIMPULAN}

Simpulan berisi secara singkat dan jelas tentang esensi dari hasil penelitian dan rekomendasi. Simpulan dipaparkan dalam satu paragraf, bukan point-point, dan diungkapkan bukan dalam kalimat statistik. Simpulan dilengkapi dengan satu paragraf saran hasil penelitian.

Berdasarkan hasil penelitian di atas, penulis dapat menarik kesimpulan yaitu Pustakawan layanan anak dalam memberikan informasi isi koleksi pada Dinas Perpustakaan dan Kearsipan Kabupaten Konawe sudah memiliki kredibilitas yang cukup baik hal ini ditunjukkan pada tiga indikator yang digunakan oleh penulis. Pada indikator keterpercayaan, pustakawan berupaya bersikap tulus, terbuka dan sabar dalam melayani pemustaka anak meskipun sikap terbuka dan sabar yang dimiliki belum sepenuhnya. Selanjutnya indikator keahlian, pustakawan pada layanan anak sudah memiliki pengetahuan tentang perpustakaan dan mengenai keterampilan, pustakawan menerapkan penyesuaikan usia pemustaka dengan bahan bacaan, melakukan kegiatan mendongeng dan membantu pemustaka anak yang kesulitan memperoleh informasi dari bahan bacaan karena keterbatasan belum bisa membaca meskipun bantuan tersebut belum konsisten dilakukan. Dan terakhir indikator daya tarik, pustakawan senantiasa memperhatikan penampilan dalam hal ini selalu menjaga kerapian dan mengikuti aturan berpakaian yang sudah ditetapkan. Berkaitan dengan daya tarik psikologis pustakawan layanan anak dalam hal ini kaitannya dengan kedekatan antara pemustaka dan pustakawan interaksi sengaja di desain menggunakan pendekatan antara Ibu dan Anak. Selain itu terdapat daya tarik lain yang berasal dari dekorasi ruangan layanan anak yang disesuaikan dengan karakteristik anak-anak yang ceria dan penyediaan fasilitas pendukung serta mengadakan kegiatan seperti pemutaran film.

Berdasarkan hasil penelitian yang telah diperoleh, maka ada beberapa saran yang bisa penulis berikan. Pertama, bagi pustakawan, sebaiknya penggunaan fasilitas dalam hal ini mainan yang ada pada layanan anak tidak dibatasi sehingga pemustaka anak bisa memanfatkannya kapanpun; Dalam melayani pemustaka anak sebaiknya pustakawan lebih bisa mengontrol emosi sehingga dapat memberikan pelayanan yang lebih optimal lagi kepada pemustaka anak; Pustakawan sebaiknya tidak mengenal waktu dan keadaan dalam membantu pemustaka anak dalam menjelasakan isi informasi bahan bacaan pada pemustaka anak yang belum bisa membaca. Kedua, bagi pemustaka anak, sebaiknya pemustaka anak lebih bisa menjaga sikap dan tidak bertingkah laku yang bisa memancing emosional pustakawan agar pemberian informasi dapat berjalan dengan lancar.

\section{DAFTAR PUSTAKA}

Akbar, Fahmi. 2017. Perbandingan Kualitas Ruang Layanan Anak Pada Dinas Perpustakaan Provinsi Jawa Tengah dan Dinas Perpustakaan Provinsi Jawa Timur. Surabaya: Universitas Airlangga.

Azwar, Saifuddin. 2011. Sikap Manusia: Teori dan Pengukurannya. Jakarta: Pustaka Pelajar.

Darmawan, Deni dan Kunkun Nur Fauzi. 2013. Sistem Informasi Manajemen. Bandung: PT Remaja Rosdakarya.

Depdiknas. 2011. Kamus Umum Bahasa Indonesia. Jakarta: Balai Pustaka.

Elfisa, Muhammad Khaironi dan Yunaldi. 2012. Layanan Anak Pada Perpustakaan Proklamator Bung Hatta Dalam Menumbuhkan Minat Baca Anak. Padang: Jurnal Ilmu Informasi Perpustakaan dan Kearsipan, 1(1): 206-214.

Hidayani, Nenden Serena. 2014. Layanan Anak Pada Perpustakaan Bank Indonesia. Jakarta: UIN Syarif Hidayatullah. 
Inayati, Widad. 2018. Peran Pustakawan Dalam Pemanfaatan Layanan Anak Sebagai Motivasi Belajar Anak di Dinas Perpustakaan Dan Kearsipan Provinsi DKI Jakarta. Jakarta: UIN Syarif Hidayatullah.

Kusumawardhani, Dwininda. (2018). Hubungan Kredibilitas Pustakawan Dengan Loyalitas Pemustaka Pada Perpustakaan Unisba. Bandung: Jurnal LIBRARIA: Jurnal Perpustakaan, 6(1): 153-174.

Larasati, Lati. 2011. Layanan Tandon di Perpustakaan Daerah Kabupaten Tegal. Surakarta: Universitas Sebelas Maret.

Mulyadi. 2011. Profesi Kepustakawanan, (Bekal Calon Pustakawan Tingkat Ahli). Palembang: Rafah Press.

Nasrullah. 2015. Kenaikan Tunjangan Fungsional dalam Meningkatkan Motivasi Kerja Pustakawan di Perpustakaan Universitas Hasanuddin Makassar. Makassar: Universitas Islam Negeri Alauddin.

Nasrullah. 2017. Peranan Pustakawan Dalam Membangun Perpustakaan Digital Di Perpustakaan Universitas Bosowa. Makassar: Universitas Islam Negeri Alauddin.

Rachmawati, Tine Silvana. 2017. Kepuasan Pengguna Ditinjau Dari Kredibilitas Staf Layanan di Perpustakaan Dan Pusat Informasi Ilmiah Fakultas Ekonomi UNPAD. Bandung: Jurnal Edulib, 7(1): 33-42.

Rakhmat, Jalaludin. 2012. Psikologi Komunikasi. Bandung: Remaja Rosda Karya.

Republik Indonesia. 2003. Undang-Undang Republik Indonesia Nomor 20 Tahun 2003 Tentang Sistem Pendidikan Nasional. Jakarta: Departemen Pendidikan Nasional.

Republik Indonesia. 2007. Undang-Undang Republik Indonesia Nomor 43 Tahun 2007 Tentang Perpustakaan. Jakarta: Perpustakaan Nasional Republik Indonesia

Saleh, Amin. 2014. Pengaruh Kredibilitas Pustakawan Pada Layanan Referensi Terhadap Kepuasan Pemustaka di Badan Perpustakaan Dan Arsip Daerah Provinsi Nusa Tenggara Barat. Mataram: Jurnal Edulib (Journal of library and information science), 1(1): 1-15.

Saleh, Abdul Rahman. 2011. Manajemen Perpustakaan. Jakarta: Universitas Terbuka.

Sigar, Hendry S, dkk. 2012. Persepsi Jemaat Terhadap Kredibilitas Pelayan Khusus Sebagai Komunikator. Jurnal Acta Diurna, 6(3): 1-13.

Sugiyono. 2010. Metode Penelitan Kuantitatif Kualitatif \& RND. Bandung: Alfabeta.

Susanto, Azhar. 2013. Sistem Informasi Akuntansi. Bandung: Lingga Jaya.

Sutarman. 2012. Pengantar Teknologi Informasi. Jakarta: Bumi Aksara.

Suwarno, Wiji. 2011. Perpustakaan \& Buku: Wacana Penulisan \& Penerbitan. Jogjakarta: Ar-Ruzz Media.

Tursi. 2015. Kredibilitas Tenaga Perpustakaan SMAN 1 Sindang Kab. Indramayu. Jatinangor: Universitas Padjajaran.

Wendri, Sispa. 2018. Analisis Pengelolaan Perpustakaan Daerah Di Kabupaten Kuantan Singingi. Pekanbaru: Universitas Islam Negeri Sultan Syarif Kasim Riau.

Winoto, Yunus. 2015. Penerapan Teori Kredibilitas Sumber (Source of Credibity) Dalam Penelitian-penelitian Layanan Perpustakaan. Bandung: Jurnal Edulib, 5(2): 1-14.

Yakub. 2012. Pengantar Sistem Informasi. Yogyakarta: Graha Ilmu.

Zulharmain, Ade. 2015. Peranan Layanan Anak di Perpustakaan Daerah Tangerang Selatan Dalam Meningkatkan Minat Baca Anak. Jakarta: UIN Syarif Hidayatullah. 